\title{
Development of Moral Beliefs in Some Principal Upanishads
}

\author{
Binita Kar \\ Lecturer Philosophy, \\ U.N.( Auto) College of Science and Technology, \\ Udaipur, Cuttack, Odisha. \\ Email:binitakbaby@gmail.com
}

Abstract: - binitakbaby@gmail.com

The reading of some of the major Upanishads reveals that not only Upanisads attempt at establishing distinct metaphysical stand but there have been recommendations of many moral principles that show that those represent the developments of moral beliefs in the Vedic and Upanisadic days. The development of moral beliefs in the Upanisads can be well visualized from the emphasis on the moral values and virtues like knowledge, truth. sacrifice (taiga), penance (tapas), donation or gift (daana), etc. In the language of Kathopanisad, all these are Shreyas for humans. There have been discussions on these aspects in Upanishadic texts. From these one can very well see that there have been strong foundations in respect of the development of moral beliefs in the Upanisads which are exposed to further refinements in the subsequent periods.

Key concepts: Shreya, Vidya, Satya, Tyaaga, Tapas, Daana

Reference to this paper should be made as follows.

Received: 21.07.2020

Approved: 30.09.2020

\section{Binita Kar}

Development of Moral Beliefs in Some

Principal Upanishads

Article No. 31

RJPSS Sept. 2020,

Vol. XLV No. 2,

pp. 259-266

Online available at:

https://anubooks.com/ ripss-2020-vol-xlv-no-2/ https://doi.org/10.31995/ rjpss.2020.v45i01.031 
Development of Moral Beliefs in Some Principal Upanishads

Binita Kar

\section{Development of Moral beliefs in Some Principal Upanisads}

The Upanisads are treated as ancient Indian treasures by many and also some others consider that these ritualistic treatises of Hinduism do not contain anything philosophically significant. But it may be pointed out that if something has to be claimed then there should be some basis behind it. The reading of some of the major Upanisads reveals that not only Upanisads attempt at establishing distinct metaphysical stand but there have been recommendations of many moral principles that show that those represent the developments of moral beliefs in the Vedic and Upanisadic days. This paper is an attempt to reflect on the treatment of moral virtues and values found in some of the principal Upanisads.

\section{The necessity of developing moral principles and virtues}

It is important to see that if there has been any necessity of developing some moral principles and virtues when the Upanisads were primarily trying to establish some metaphysical stand. Such a question is raised for this reason that what is the role of morality for the attainment of higher knowledge? So far as the view of Upanishads is concerned usually it is taken for granted that everyone is under the spell of ignorance (avidya). Knowledge is possible when avidya can be removed. And the removal of knowledge is possible by obtaining the knowledge of the ultimate reality. The knowledge of the reality has been expressed in various mahaavaakyas (great sentences) of the Upanisads. Four such mahaavaakyas are found in the following manner.

1. Prajnanam Brahman - Consciousness is Brahman. (Aitareya Upanisad V.3), Rg. Veda.

2. Tat Tvam Asi - That Thou Art. (Chandogya Upanisad- VI.8.7), Sama Veda.

3. Aham Brahmasmi - I am Brahman. (Brihadaranyaka Upanisad I.4.10), Yajur Veda

4. Ayam Atma Brahma - This self is Brahman. (Mandukya Upanisad), Atharva veda and from (Brihadaranyaka Upanisad- II.5.19

The knowledge revealed by the mahaavaakyas is more or less the same that all of them point towards the relationship between single ultimate reality, Brahman, and the atman. There is the relation of identity between the two and the knowledge of this removes ignorance and leads to the ultimate goal of the life that is moksa. Thus the question rose earlier regarding the necessity of the moral principles and 
RJPSS Sept. 2020 Vol. XLV No.2, ISSN: (P)0258-1701 (e)2454-3403 Impact Factor: 7.717 https://doi.org/10.31995/rjpss.2020.v45i01.031 virtues in the process of obtaining such knowledge becomes significant. In order to find out an answer, I feel to proceed with the following views of the Kathopanisad, Brhadaranyaka Upanisad, Taittiriya Upanisad, Mundaka Upanisad, Maitree Upanisad, and Isopanisad.

Brahma-jnana happens to be the ultimate goal of life as it is the only way to obtain parama purusartha, moksa. Kathopanisad makes it clear that such an opportunity is not open for all. The moral perfection is an essential prerequisite of obtaining the higher knowledge. It has been said that who has not been refrained himself from the evil paths or from wickedness (naavirato duscaritaan) he cannot attain the higher knowledge (prajnanenainam aapnuyaat) ${ }^{1}$. Referring to this Radhakrishnan writes that "Saving wisdom cannot be obtained without the moral qualifications here mentioned. No one can realize the truth without illumination, and no one can have illumination without a thorough cleansing of one's moral being." 2 In different words this view has been placed that the worldly man bereft of inner and outer purity cannot know the Atman and Brahman. "A total discipline of the inner life, beginning with moral purity, is demanded of the student who is not content to know the Atman intellectually but seeks to realize It spiritually. Moral purity and discipline of the senses help to lead man into the stream of spirituality leading to the ocean of spiritual realization." 3 Radhakrishnan rightly points out the view of the Upanisad that "If we wish to attain spiritual, we cannot bypass the ethical." 4 undaka Upanisad also agrees to this view in a different footing with the words that the self is attainable "by truth, by austerity, by right knowledge, by the constant (practice) of chastity." 5

Becoming free from evil as a necessary condition for aatmajnaana is also emphasized in the Brhadaranyaka Upanisad in the following manner. It is suggested that one should know the nature of Brahman. 'Having found that one is not tainted with evil action. Therefore he who knows it as such had become calm, self-controlled, withdrawn, patient and collected sees the self in his own self, sees all in the Self. Evil does not overcome him, he overcomes all evil.' ${ }^{6}$ This shows that involvement with evil is a strong barrier to the attainment of higher knowledge. To become free from evil is to become morally perfect. The Upanishadic seers simply did not warn to be away from evil but have positively suggested cultivating virtues to achieve moral perfection which is a necessary condition for the highest goal of the life. Kathopanisad suggests that the three duties, namely, the study of scriptures, performance of sacrifice, and giving alms are to be performed in order to attain 
Development of Moral Beliefs in Some Principal Upanishads

Binita Kar

swarga. The importance is attached to the attainment swarga for the reason that swarga is free from all kinds of human miseries like disease, old age, death, etc. However, the purpose of mentioning this view is that the three things (the study of scriptures, performance of sacrifice, and giving alms) treated to be valuable for man are all virtues that should be cultivated by man.

Tiwari points out that "The ethical virtues (or duties) so often emphasized in the Upanisads are - Satya (truth), yajna (sacrifice), tapas (penance), dana (liberality), adhyayana (the study of the Vedas), self-control, compassion, right dealing, etc. One can see very clearly that the list includes regarding both the individual and social morality." 7

The development of moral beliefs in the Upanisads can be well visualized from the emphasis on the moral values and virtues like knowledge, truth. sacrifice (taiga), penance (tapas), donation or gift- liberality (daana), etc. In the language of Kathopanisad, all these are Shreyas or moral values. In this context, the importance of the knowledge of the Shreya and the prey as mentioned in the Kathopanisad is very much significant.

The opening verse of the chapter two of the part one of the Kathopanisad deals with concepts of Shreya and prey. Here it has been pointed out that wise men know the difference between choosing Shreyas and preys for their living. Both Shreya and prey influence man in various ways. Only intelligent and noble (sadhu) people choose Shreya in order to obtain a higher goal of life. But others choose prey for the sake of their growth and development and remain away from their goal. Praharaj writes that "it has now become very much clear that the prey stands for an instrumental value of mundane value which man pursues for his growth and sustenance. But it is not a higher value, rather detrimental for higher knowledge. It is required for the socalled happy life or pleasant living. It refers to pragmatic good. It refers to those which are found to be useful in our day to day living. So the preyas refer to those which are usually desired." "So opting prey no one can avail the goal of his life. For that one has to opt for the ethical values or the Shreyas. Here it is worth quoting the view of Ranganathananda that "Ethics begins with parting from prey and entering the path of Shreya; from then on, man ascends from the organic to the mental, and thence to spiritual, dimensions of his being, liberating the value of humanness in the process, to rise, in the end, step by step, to the full stature of his selfhood."9 Thus through the teachings regarding the different impacts of the preys and the Shreyas the importance of the moral values has been pointed out in the Kathopanisad. 
RJPSS Sept. 2020 Vol. XLV No.2, ISSN: (P)0258-1701 (e)2454-3403 Impact Factor: 7.717

https://doi.org/10.31995/rjpss.2020.v45i01.031

\section{The Shreyas:}

\section{(a) Knowledge}

One of the most significant aims of the Upanisads is to show the distinction between vidya and avidya. Upanisads believe in the maxim: avidya ya vimuktaye. Knowledge is essential. It has already been made clear that according to the Upanisads the moral perfection is the gate pass for the right knowledge. The link between knowledge and moral life are inseparable for the Upanisads.

\section{(b) Truth}

Truth as a preferable value is unquestionable. The ancient seers of the past, both in the East and the West truth have been recognized as an ultimate or absolute value. The Upanisads have always attempted at reaching at satyasya Satyam. In the west, the most civilized Greek tradition three things have been treated as ultimate values. Those are namely, Truth, Goodness, and Beauty. In the Upanisadic tradition, the emphasis on the ultimate values likes, Sat, Chit, and Ananda is also quite conspicuous.

Truth has been treated to be very precious in the Ishopanisad. It has been said that the truth is there in a covered golden pot. It is necessary to uncover it to know it. ${ }^{10}$ The significance of this statement is that truth, which is in conformity with reality, is not available openly. One has to take the resort of someone who can help in knowing the truth. It is essential for the lover the truth.

In Taittiriya Upanisad, the teacher addresses the students after completion of studies, "Satyam vada, dharmam chara, (Speak the truth, practice virtue), ....Satyan pramaditavyam (let there be no neglect of truth), dharma and pramaditavyam (let there be no neglect of virtue), ...." It It shows that Upanisads have attached an emphasis on truth as a basic moral belief.

\section{(c) Penance (tapas)}

In the Upanisadic tradition, tapas is considered as the means of renunciation. It is a character-building value. It is essential for obtaining the higher knowledge. The tapas are consisting of knowledge and the universe is the result of the tapas of the Creator has been maintained in the Mundaka Upanisad. ${ }^{12}$ Commenting upon this Sankara says that 'Whose tapas consists of thoughts; it is just a form of His knowledge, which is of the nature omniscience; it is a tap characterized by effortlessness or spontaneity. ${ }^{.13}$

In the Maitree Upanisad it has been said that "This is the door to Brahman, said one who had freed himself from evil by (the practice of) austerity. ... Therefore, by knowledge, by austerity, by meditation is Brahman apprehended."14 
Development of Moral Beliefs in Some Principal Upanishads

Binita Kar

Ranganathananda points out that tapas plays a vital role in human evolution. "It unites the citizen and the saint, the scientist, and the artist in a common discipline and quest, thus bridging the gulf between the secular and the sacred." ${ }^{15}$ For this noble step of 'intellectual, moral, and spiritual growth of man' the contribution of the Upanisads is remarkable.

The emphasis on tapas is often criticized as self-oriented and ascetic. ${ }^{16}$ The practice of it is in no way helpful for others and the society. On tapas, Surama Dasgupta writes that "The concept of tapas in the Upanisads is, however, of a pure nature. It probably means energy or self-effort, thought, self-control, or study, and it is regarded not as a means to the attainment of mundane or extra-mundane benefits, but as a means to enlightenment or self-knowledge." ${ }^{17}$ It cannot be denied that the attainment of the self-knowledge happens to be the primary goal so far as the Upanishadic trend is concerned. But it is not detrimental in the promotion of the ethical values in the sense; the purification of the soul is considered as the essential prerequisite for the attainment of self-knowledge. And for purification, the practice of the moral virtues are equally essential.

\section{(d) Donation or gift (daana)}

Daana as pious and virtuous deed followed from the Vedic and Upanishadic period. This practice can be considered both as individual virtue and social virtue in the sense it involves individual psychology and the redistribution of the wealth. Donating something for the cause of the society was treated to be a higher order of work because to a great extent the practice was able to fulfill the mutual needs during that economically backward days. During those days almsgiving, charity, donating food, and clothes to the brahmins and poor people were coming under the virtuous deed as daana.

It is almost clear that daana was associated with another activity that is yajna (sacrifices) where the recipients of daana were priests. It was taken for granted that through daana one can please God and it will help in the practice of detachment or renunciation. To a great extent, it was ethical. But the spirit of the Rigveda, that daana should be performed because it will bring prosperity to the donor is not ethically sound. It is because the donor neither should feel the loss of the property donated nor should expect anything in return. However, daana had the feature of sacrificial oblation and primarily it was referring to the giving to priests who were officiating sacrifices in different religious ceremonies. ${ }^{18}$ Referring to the expression tena taken bhunjithaa of the first verse of the Ishopanisad Swamy Chinmayananda 
RJPSS Sept. 2020 Vol. XLV No.2, ISSN: (P)0258-1701 (e)2454-3403 Impact Factor: 7.717

https://doi.org/10.31995/rjpss.2020.v45i01.031

says that the ideal of charity or daana "can be read into this phrase. Giving is the true enjoyment of wealth." 19

\section{(e) Sacrifice (taiga)}

It may be made clear that although very often the most popular act of performing yajna is treated as 'sacrifice', here 'sacrifice' would be discussed in the sense of renunciation or taiga. Tyga happens to one of the most important virtues recommended in the Upanisads to be cultivated while preparing for the attainment of the highest goal. Swamy Chinmayananda writes that "At one period of history men are apt to advocate, encourage and live the life of renunciation and pure knowledge while following it comes to the other wave of a revolt against this life of quiet growth and inward culture, and in its place history carves out a wild outward civilization of material gains and physical comforts. ${ }^{20} \mathrm{He}$ has given this opinion in the context of the commentary given for the first verse of the Ishopanisad.

There is the least doubt that in the Upanisads there have been recommendations for renunciation to achieve the higher state. We have seen that many moral virtues are recommended by the Upanisads along with the emphasis on the primary goal of the life. But at the same time, those are criticized as individualistic. It is because those are cultivated for their own advantage or own enlightenment. Ruth Reyna has opined that "Upanisadic ethics is primarily concerned with selfdiscipline leading to the liberation of the individual." ${ }^{21}$ But I would like to agree with the defense given by Mrs. Kar with the words "renunciation of all such worldly desires like those originated due to the craving for wealth, etc. is not advocated for one's own selfish interest. It is not that one is to attain his own highest end by neglecting others, resigning or withdrawing from our normal course of duties and responsibilities. That is surely not the suggestion of either of Ishaa Upanisad or of the general Upanishadic point of view. Renunciation of action is never to be confused with the resignation or abandonment of action." ${ }^{22}$ Thus we can very well realize that there have been strong foundations in the development of moral beliefs in the Upanisads which are exposed to further refinements in the subsequent periods.

\section{References}

1. Kathopanisad, $1,2,24$

2. Radhakrishnan, S., The Principal Upanisads, Harper Collins Publishers India, 1999 edition, p. 620.

3. Ranganathananda, Swami, The Message of the Upanisads, Bharatiya Vidya Bhavan, Bombay, 1993, p. 392.

4. OP cit (2), p. 620 
Development of Moral Beliefs in Some Principal Upanishads

Binita Kar

5. Satyena labhyas tapasaa hy esa aatma samyag-jnanena brahmacaryena nityam, III, 1, 5 .

6. Bhadaranyaka Upanisad, IV.4. 24.

7. Tiwari, K.N., Classical Indian Ethical Thought, Motilal Banarsidass Publishers Private Ltd. Delhi, 2014, p. 80.

8. Praharaj, D. M., Philosophy of the Vedas and the Upanisads, Kalyani Publishers, 2014, p.70.

9. Ranganathananda, Swami, The Message of the Upanisads, Bharatiya Vidya Bhavan, Bombay, 1993, p. 293.

10. Hiranmayena paatrena satyasya apahitam mukham, XV

11. Taittiriya Upanisad 1.11

12. Tasya jnanamayam tapah, (1.I.9)

13. Yasya jnaanamayam jnaanavikaarameva saarvajnyalaksanam tapo anaayaasalaksanam

14. Maitree Upanisad, IV. 4.

15. Ranganathananda, Swami, The Message of the Upanisads, Bharatiya Vidya Bhavan, Bombay, 1993, p. .377

16. Radhakrishnan, S., The Principal Upanisads, Harper Collins Publishers India, 1999 edition, p.109

17. Dasgupta, Surama., Development of Moral Philosophy in India, Orient Long Mans, 1961, p. 70.

18. Nath, V., Daana: Gift System in Ancient India. Munshiram Manoharlal Publishers, (1987). P.15

19. Chinmayananda, Swamy. Ishavaasya Upanisad, Central Chinmaya Mission Trust, Reprint 2000, p.64.

20. Chinmayananda, Swamy. Ishavaasya Upanisad, Central Chinmaya Mission Trust, Reprint 2000, p.66.

21. Reyna, Ruth. Introduction to Indian Philosophy, MC Graw Hill Publication, 1971, p.42.

22. Kar Namita, Humanistic Trends in Some Principal Upanisads, Ajanta Publications, 1989, p.18. 